\title{
Characterization of Dried and Torrefied Arundo Donax Biomass for Inorganic Species Prior to Combustion
}

\author{
J Matyáš \\ BR Johnson \\ JE Cabe
}

August 2012

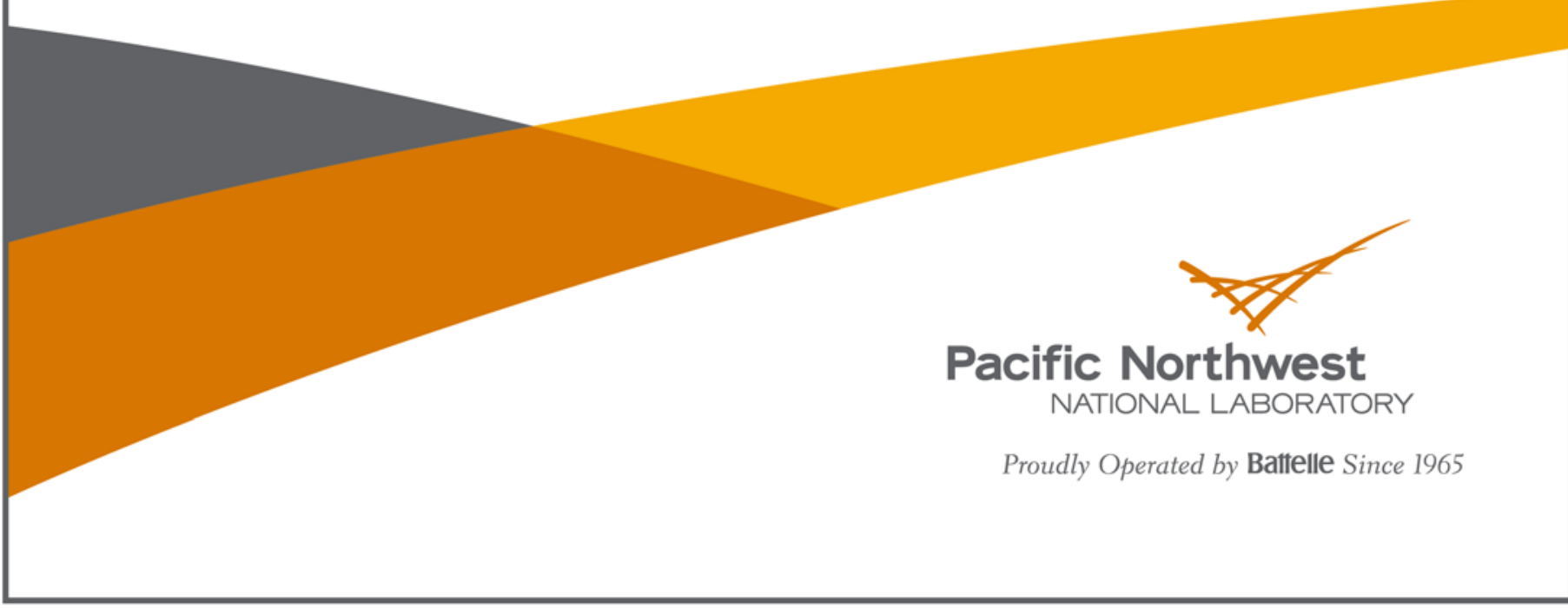




\title{
DISCLAIMER
}

This report was prepared as an account of work sponsored by an agency of the United States Government. Neither the United States Government nor any agency thereof, nor Battelle Memorial Institute, nor any of their employees, makes any warranty, express or implied, or assumes any legal liability or responsibility for the accuracy, completeness, or usefulness of any information, apparatus, product, or process disclosed, or represents that its use would not infringe privately owned rights. Reference herein to any specific commercial product, process, or service by trade name, trademark, manufacturer, or otherwise does not necessarily constitute or imply its endorsement, recommendation, or favoring by the United States Government or any agency thereof, or Battelle Memorial Institute. The views and opinions of authors expressed herein do not necessarily state or reflect those of the United States Government or any agency thereof.

\author{
PACIFIC NORTHWEST NATIONAL LABORATORY \\ operated by \\ BATTELLE \\ for the \\ UNITED STATES DEPARTMENT OF ENERGY \\ under Contract DE-AC05-76RL01830
}

Printed in the United States of America
Available to DOE and DOE contractors from the Office of Scientific and Technical Information, P.O. Box 62, Oak Ridge, TN 37831-0062; ph: (865) 576-8401 fax: $(865)$ 576-5728
email: reports@adonis.osti.gov

Available to the public from the National Technical Information Service 5301 Shawnee Rd., Alexandria, VA 22312 ph: (800) 553-NTIS (6847) email: orders@ntis.gov $<$ http://www.ntis.gov/about/form.aspx $>$ Online ordering: http://www.ntis.gov 


\title{
Characterization of Dried and Torrefied Arundo Donax Biomass for Inorganic Species Prior to Combustion
}

\author{
J Matyáš \\ BR Johnson \\ JE Cabe
}

August 2012

Prepared for

the U.S. Department of Energy

under Contract DE-AC05-76RL01830

Pacific Northwest National Laboratory

Richland, Washington 99352 



\section{Summary}

Portland General Electric (PGE) potentially plans to replace the coal feedstock with torrefied Arundo donax (giant cane) for their Boardman coal-fired power plant by 2020. Since there is only a limited amount of experience with this high yield energy crop and its combustion for the generation of power, PGE would like to characterize dried and torrefied Arundo donax before a test burn and therefore avoid possible ash related operational problems such as slagging, deposit formation and corrosion.

This report describes the results from characterization of ground and cross-sectioned samples of dried and torrefied Arundo donax biomass with high-resolution scanning electron microscopy (SEM), and energy dispersive spectroscopy (EDS), and also includes analytical results from a short water-leaching test for concentrations of $\mathrm{Ca}, \mathrm{Mg}, \mathrm{K}, \mathrm{Na}, \mathrm{S}$, and $\mathrm{Cl}$ in the non-leached and leached Arundo donax and leachates.

SEM-EDS analysis of torrefied Arundo donax revealed that condensation of volatile components K, $\mathrm{Cl}$, and $\mathrm{S}$ during torrefaction can result in their undesirable re-deposition on the outside surfaces in the form of amorphous or crystallized clusters of salts $\mathrm{KCl}$ and $\mathrm{K}_{2} \mathrm{SO}_{4}$ with a size from a few micrometers to as large as $100 \mu \mathrm{m}$. A short exposure of Arundo donax to water resulted in an efficient removal of volatile species from the dried and torrefied Arundo donax, e.g., $\sim 98 \mathrm{wt} \%$ of total $\mathrm{K}$ and $\mathrm{Cl}$, and $\sim 75 \mathrm{wt} \%$ of total S were removed from dried Arundo donax, and more than $90 \mathrm{wt} \%$ of total $\mathrm{K}$ and $\mathrm{Cl}$, and $70 \mathrm{wt} \%$ of S from torrefied Arundo donax, suggesting that water-leaching of Arundo donax before combustion can be an effective pre-treatment method because high concentrations of $\mathrm{Cl}$ increase emissions of $\mathrm{HCl}$, and in combination with $\mathrm{K}$ can form large amounts of $\mathrm{KCl}$ deposits on boiler surfaces and in combination with $\mathrm{H}_{2} \mathrm{O}$ or $\mathrm{SO}_{3}$ cause corrosion. 



\section{Contents}

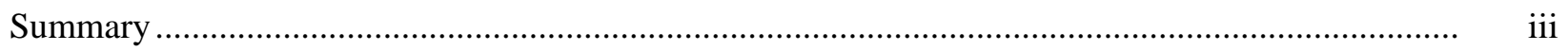

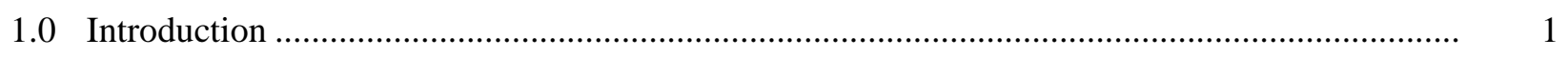

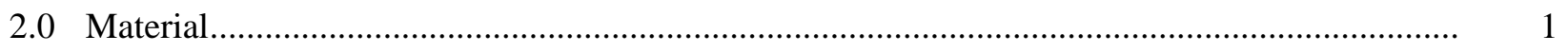

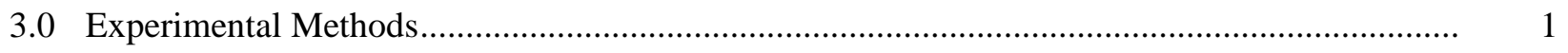

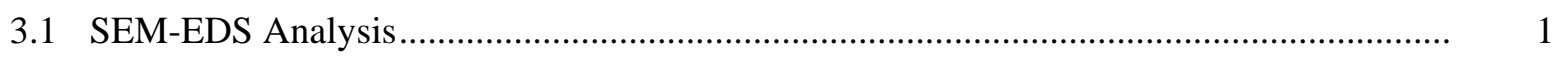

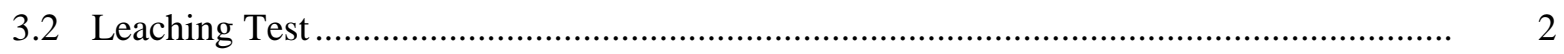

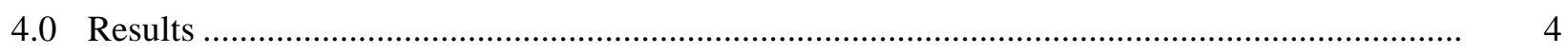

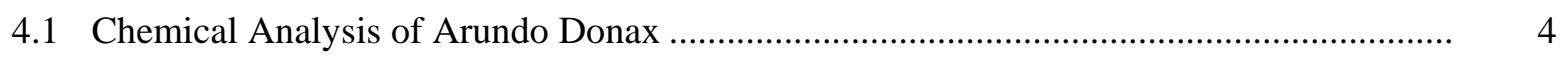

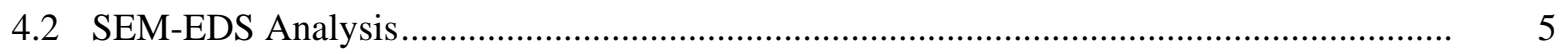

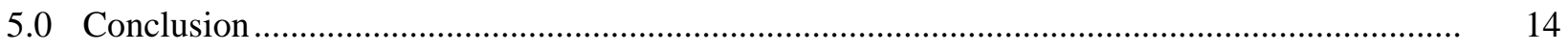

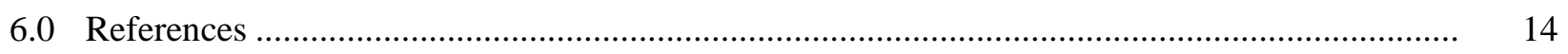

\section{Figures}

1 Optical Images of As-Received Dried and Torrefied Arundo Donax....................................... 2

2 Optical Images of Ground Dried and Torrefied Arundo Donax .............................................. 2

3 SEM Images of K, Cl, and S-Rich Deposits on a Backbone of Ground Torrefied Arundo

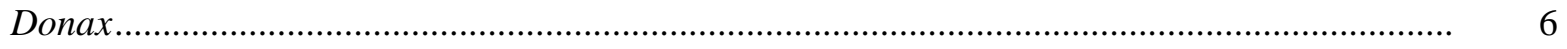

4 SEM Image of K, Cl, and S-Rich Deposits on a Backbone of Ground Torrefied Arundo

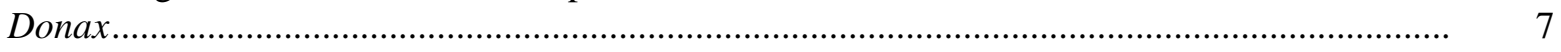

5 SEM Image of KCl Condensate on a Backbone of Ground Torrefied Arundo Donax................ 7

6 SEM Image of $\mathrm{K}, \mathrm{Cl}$, and S-Rich Deposits on a Backbone of Ground Torrefied Arundo

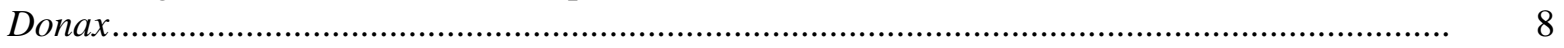

7 Elemental Dot Map of K, Cl, S-Rich Deposits for Ground Torrefied Arundo Donax.................. 9

8 SEM Image of a Backbone for Ground Dried Arundo Donax .................................................. 9

$9 \quad$ SEM Image of a Backbone for Ground Dried Arundo Donax ...................................................... 10

10 Cross-Section for As-Received Torrefied Arundo Donax (inside) ............................................ 11

11 Cross-Section for As-Received Torrefied Arundo Donax (side) ............................................... 11

12 Elemental Dot Map of $\mathrm{SiO}_{2}$ Skin in As-Received Torrefied Arundo Donax.............................. 12

13 Cross-Section for As-Received Dried Arundo Donax (inside) ..................................................... 12

14 Cross-Section for As-Received Dried Arundo Donax (top skin)................................................ 13

15 Cross-Section for As-Received Dried Arundo Donax (detail of top skin)..................................... 13 


\section{Tables}

1 Theorerical and Measured Concentrations in $\mathrm{mg} / \mathrm{kg}$ and Percent Recoveries for Ca, Mg, P, $\mathrm{K}, \mathrm{Na}, \mathrm{S}$, and $\mathrm{Cl}$ in the Lab Control Samples

2 Theoretical and Measured Concentrations in $\mathrm{mg} / \mathrm{kg}$ and Percent Recoveries for Ca, Mg, $\mathrm{K}$, $\mathrm{Na}, \mathrm{S}$, and $\mathrm{Cl}$ in the Aqueous Lab Control Samples

3 Concentrations of $\mathrm{Ca}, \mathrm{Mg}, \mathrm{P}, \mathrm{K}, \mathrm{S}$, and $\mathrm{Cl}$ in $\mathrm{mg} / \mathrm{kg}$ in the Dried and Torrefied Arundo Before and After Leaching in DIW

4 Concentrations of $\mathrm{Ca}, \mathrm{Mg}, \mathrm{P}, \mathrm{K}, \mathrm{S}$, and $\mathrm{Cl}$ in $\mathrm{mg} / \mathrm{kg}$ in the Leachates from Dried and Torrefied Arundo

5 Concentrations of Elements in wt\% for Selected Areas of Ground Torrefied Arundo Donax.

6 Concentrations of Elements in wt\% for Selected Areas of Ground Dried Arundo Donax 


\subsection{Introduction}

Portland General Electric (PGE) potentially plans to replace the coal feedstock with torrefied biomass for their Boardman coal-fired power plant by 2020 or shut the plant down. They are considering Arundo donax (giant cane) as a fuel because of its high yield of 20-25 tons per acre (BG\&E 2007), rapid growth of 5-10 cm per day (BG\&E 2007; Quinn and Holt 2003), and high energy content of torrefied Arundo donax 10,000 Btu per pound (Lei 2012). But this herbaceous crop has the potential for high ash content, which can lead to problems in combustion, gasification, and pyrolysis (Dahl and Obernberger 2004). Since there is only a limited amount of experience with combusting or thermally deconstructing this high yield energy crop, PGE would like to characterize Arundo donax before a test burn and therefore avoid possible ash related operational problems such as slagging, deposit formation and corrosion.

This report describes the results from characterization of dried and torrefied Arundo donax samples with high-resolution scanning electron microscopy and energy dispersive spectroscopy (SEM-EDS). In addition, a short water-leaching test was performed at room temperature to determine the quantities of problematic elements, such as $\mathrm{Ca}, \mathrm{Mg}, \mathrm{K}, \mathrm{Na}, \mathrm{S}$, and $\mathrm{Cl}$, that can be removed from dried and torrefied Arundo donax before combustion.

\subsection{Material}

Idaho National Laboratory provided samples of dried and torrefied Arundo donax. Dried Arundo donax was produced from raw Arundo donax by a two-step process: grinding with a hammer mill and drying in a rotary drum dryer at $120^{\circ} \mathrm{C}$ for $15 \mathrm{~min}$. Dried Arundo donax passed through the screen size of $25.4 \mathrm{~mm}$, had a moisture content $5.11 \mathrm{wt} \%$, and contained $44.97 \mathrm{wt} \%$ of carbon (C), $5.58 \mathrm{wt} \%$ of hydrogen $(\mathrm{H}), 1.87 \mathrm{wt} \%$ of nitrogen $(\mathrm{N})$, and $47.3 \mathrm{wt} \%$ of oxygen $(\mathrm{O})$. Torrefied Arundo donax which had a moisture content $0.63 \mathrm{wt} \%$ and contained 56.51, 4.41, 3.01, and $35.89 \mathrm{wt} \%$ of $\mathrm{H}, \mathrm{C}, \mathrm{N}, \mathrm{O}$, respectively, was produced by heat-treating a dried Arundo donax in a moving bed reactor at $270^{\circ} \mathrm{C}$ under $\mathrm{N}_{2}$ for 30 min. Figure 1 shows the morphology of samples for dried (A) and torrefied (B) Arundo donax. A coffee grinder with extra fine setting was used to ground as-received samples to pass through the screen size $1 \mathrm{~mm}$ (18 U.S. mesh size) for SEM-EDS analysis and leaching testing. The morphology of ground dried (A) and torrefied (B) Arundo donax is shown in the Figure 2.

\subsection{Experimental Methods}

\subsection{SEM-EDS Analysis}

Two sets of samples were investigated with SEM JSM-7001F/TTLS (JEOL Ltd., Tokyo, Japan) equipped with a field emission gun and capable of examining specimens under variable pressure conditions, allowing them to be evaluated without a conductive coating. The first set of samples were ground Arundo donax, which were analyzed directly without any preparation. The second set were cast in epoxy and prepared as polished cross-sections of as-received Arundo donax. The cross-sections were produced by mounting 2-cm straws of dried and torrefied Arundo donax into an epoxy puck, cutting the puck in half with a diamond saw to reveal their cross-sections and then polishing them using 6-, 3-, 1-, 
and 0.25- $\mu \mathrm{m}$ diamond suspensions. The specimens were sputter-coated with Pd before the analysis. The samples were investigated with secondary electron and backscattered electron detectors to obtain optimum topological as well as atomic number contrast images. Elemental analysis was performed with EDS equipped with a peltier-cooled silicon drift detector (EDAX, Mahwah, New Jersey).

A

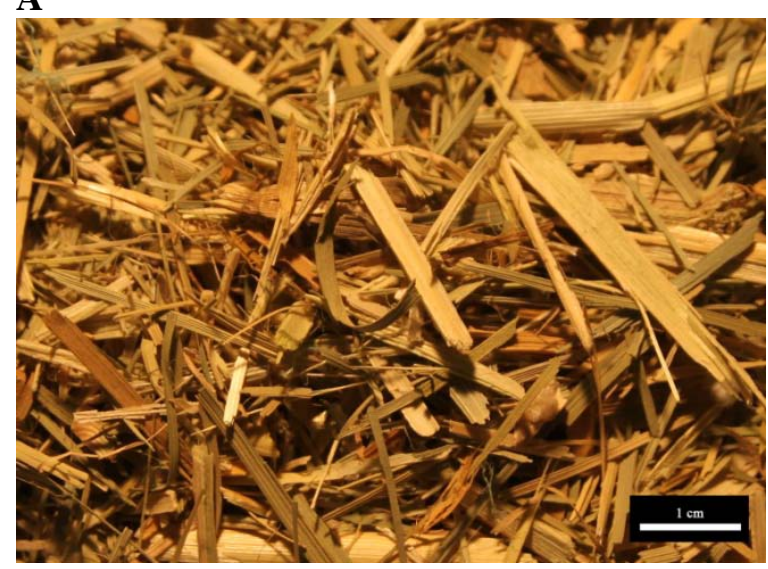

B

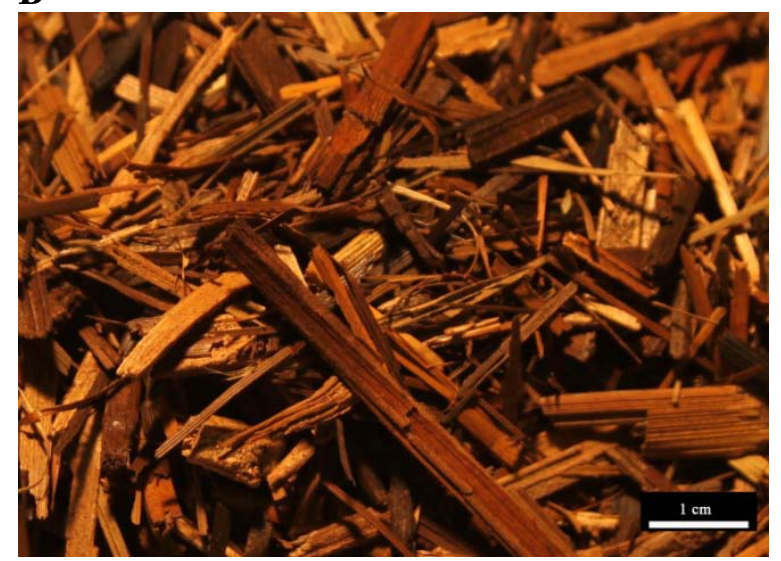

Figure 1. Optical Images of As-Received Dried (A) and Torrefied (B) Arundo Donax (straws passed through a 25.4-mm screen size)

A

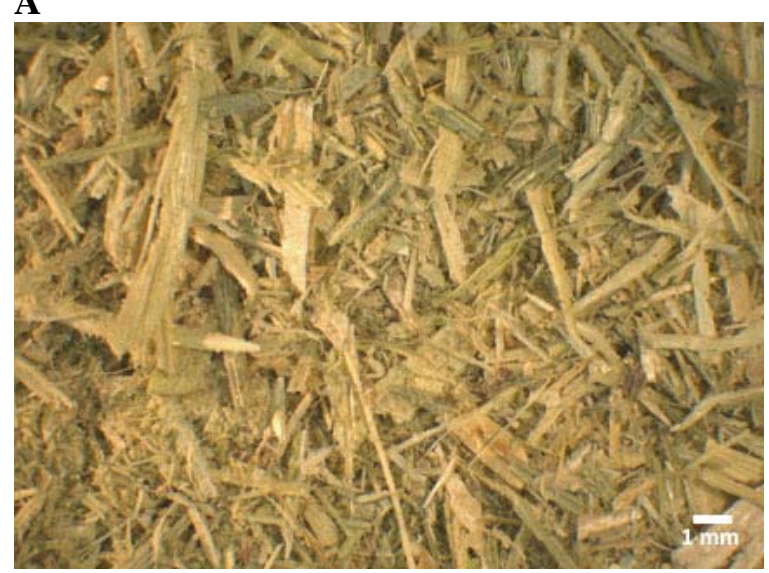

B

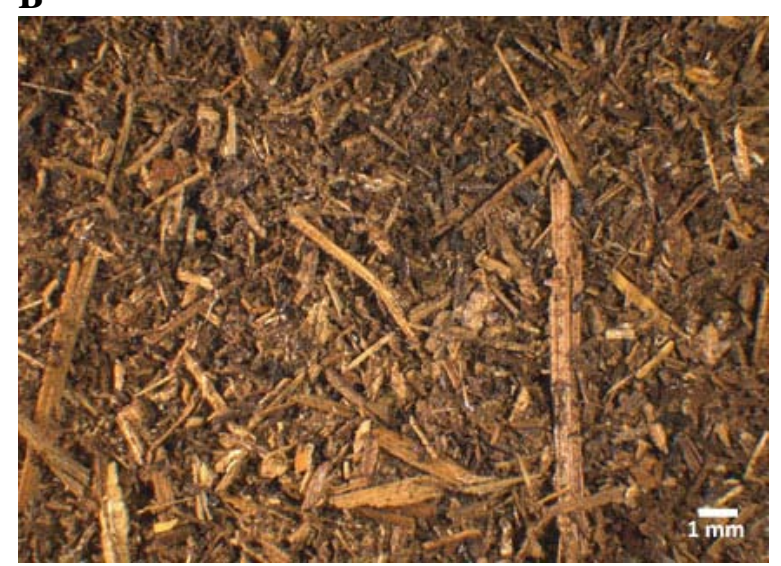

Figure 2. Optical Images of Ground Dried (A) and Torrefied (B) Arundo Donax (straws passed through 18 U.S. mesh size)

\subsection{Leaching Test}

Approximately 0.5-g samples of ground dried and torrefied Arundo donax (Samples \#1 and \#2) were transferred into 50 -mL beakers containing $40 \mathrm{~mL}$ of deionized water (DIW). Samples were leached at room temperature and under periodic stirring with a glass rod. After $1 \mathrm{~h}$ of leaching, the solids were recovered on the filter paper, washed with small amounts of DIW, and dried overnight in the oven at $55^{\circ} \mathrm{C}$ (Samples \#3 and \#4). The leached solutions were transferred into $100-\mathrm{ml}$ volumetric flasks that were filled up to the mark with DIW and then mixed in the shaker for 2 min (Samples \#5 and \#6). 
Collected samples of Arundo donax before and after leaching, and leachates were sent out to Southwest Research Institute (SwRI, San Antonio, Texas) for Ca, Mg, P, K, Na, S, and Cl analysis. The solid samples of Arundo donax were digested in $\mathrm{HNO}_{3}$ at $200{ }^{\circ} \mathrm{C}$ using microwave digestion. The leachates were digested according to U.S. Environmental Protection Agency (EPA) SW-846 Method 3005A (EPA 1992) after their $\mathrm{pH}$ was adjusted with $\mathrm{HNO}_{3}$ to less than 2. The digestates were then analyzed for $\mathrm{Ca}, \mathrm{Mg}, \mathrm{P}, \mathrm{K}, \mathrm{Na}$, and $\mathrm{S}$ by inductively coupled plasma atomic emission spectroscopy. Two solid Lab Control samples (NIST SRM 1515 Apple Leaves and NIST SRM 1573A Tomato Leaves) were digested with the samples. Bomb oxidation according to EPA SW-846 Method 5050 (EPA 1994) was used to determine the total $\mathrm{Cl}$ content in the solid samples. The samples were oxidized by combustion in a bomb containing dodecane and oxygen under pressure. The released elements were absorbed in a sodium carbonate/sodium bicarbonate solution and then analyzed with an ion chromatography (IC) analysis according to EPA Method 300.0 (EPA 1993). The leachates required no prior preparation and were directly analyzed by IC at a dilution factor of 5X. An aqueous Lab Control sample was prepared in duplicate and analyzed with the samples.

Table 1 shows the theoretical and measured concentrations in $\mathrm{mg} / \mathrm{kg}$, and percent recoveries for Ca, Mg, P, K, Na, S, and Cl in the Lab Control samples SRM 1515 and SRM1573A. The recoveries were within $81 \%-94 \%$ for the requested analytes. Table 2 shows the theoretical and measured concentrations in $\mathrm{mg} / \mathrm{L}$, and percent recoveries (94\%-100\%) for Ca, $\mathrm{Mg}, \mathrm{K}, \mathrm{Na}, \mathrm{S}$, and $\mathrm{Cl}$ in the aqueous Lab Control sample.

Table 1. Theoretical and Measured Concentrations in mg/kg and Percent Recoveries for Ca, Mg, P, K, $\mathrm{Na}, \mathrm{S}$, and $\mathrm{Cl}$ in the Lab Control Samples (SRM 1515 and SRM 1573A)

\begin{tabular}{ccccccccc}
\hline Sample \# & Values & $\mathrm{Ca}$ & $\mathrm{Mg}$ & $\mathrm{P}$ & $\mathrm{K}$ & $\mathrm{Na}$ & $\mathrm{S}$ & $\mathrm{Cl}$ \\
\hline SRM 1515 & theoretical & 15,260 & 2710 & 1590 & 16,100 & 24 & 1800 & 579 \\
& measured & 14,300 & 2500 & 1410 & 14,100 & -- & 1640 & 471 \\
& recovery, \% & 93.7 & 92.3 & 88.7 & 87.6 & -- & 91.1 & 81.3 \\
SRM 1573A & theoretical & 50,500 & 12,000 & 2160 & 27,000 & 136 & 9600 & N/A \\
& measured & 45,500 & 10,100 & 1990 & 24,600 & 114 & 8990 & N/A \\
& recovery, \% & 90.1 & 84.2 & 92.1 & 91.1 & 83.8 & 93.6 & N/A \\
\hline$--\quad=$ Not measured. & & & & & & & \\
N/A $=$ Not applicable.
\end{tabular}

Table 2. Theoretical and Measured Concentrations in $\mathrm{mg} / \mathrm{kg}$ and Percent Recoveries for Ca, Mg, K, Na, $\mathrm{S}$, and $\mathrm{Cl}$ in the Aqueous Lab Control Sample

\begin{tabular}{ccccccr}
\hline Values & $\mathrm{Ca}$ & $\mathrm{Mg}$ & $\mathrm{K}$ & $\mathrm{Na}$ & $\mathrm{S}$ & \multicolumn{1}{c}{$\mathrm{Cl}$} \\
\hline theoretical & 20 & 20 & 20 & 20 & 2 & 200 \\
measured (duplicate) & 20,20 & 20,20 & $19,18.9$ & $19.3,19.3-$ & $1.97,2$ & $204,--$ \\
recovery (duplicate), $\%$ & 100 & 100 & $95,94.5$ & 96.5 & $98.5,100$ & 98.0 \\
\hline$--=$ Not measured. & \multicolumn{7}{c}{} \\
\hline
\end{tabular}




\subsection{Results}

\subsection{Chemical Analysis of Arundo Donax}

Table 3 shows the concentrations of $\mathrm{Ca}, \mathrm{Mg}, \mathrm{P}, \mathrm{K}, \mathrm{Na}, \mathrm{S}$, and $\mathrm{Cl}$ in $\mathrm{mg} / \mathrm{kg}$ for the ground dried and torrefied Arundo donax before and after leaching in DIW. Torrefied Arundo donax contained slightly higher concentration of $\mathrm{K}(2.5 \mathrm{wt} \%)$ and $\mathrm{Cl}(0.6 \mathrm{wt} \%)$ than dried Arundo donax but the concentration of other elements were similar. Comparing before and after leaching concentrations revealed that a short leaching in water can remove a large fraction of unwanted elements from Arundo donax with higher removal efficiencies observed for dried Arundo donax. About $52 \mathrm{wt} \%$ of total Ca, $78 \mathrm{wt} \%$ of total Mg, 80 wt\% of total P, $98 \mathrm{wt} \%$ of total K, $70 \mathrm{wt} \%$ of total Na, $75 \mathrm{wt} \%$ of total S, and $98 \mathrm{wt} \%$ of total Cl was removed from dried Arundo donax, whereas for torrefied Arundo $15 \mathrm{wt} \%$ of total Ca, $40 \mathrm{wt} \%$ of total Mg, $55 \mathrm{wt} \%$ of total P, $91 \mathrm{wt} \%$ of total K, $71 \mathrm{wt} \%$ of total S, and $97 \mathrm{wt} \%$ of total Cl was leached out into water. Highly efficient leaching of elements from dried Arundo donax was validated by Table 4 that shows the concentrations of $\mathrm{Ca}, \mathrm{Mg}, \mathrm{P}, \mathrm{K}, \mathrm{Na}, \mathrm{S}$, and $\mathrm{Cl}$ in $\mathrm{mg} / \mathrm{kg}$ in the leachates. It is expected that the leaching time can be shortened and leaching rates further increased with water turbulent flow and/or heated water.

A total mass balance (summed-up concentrations of elements in the leached solids and leachates) indicated a good agreement with total concentrations of $\mathrm{Ca}, \mathrm{Mg}, \mathrm{P}, \mathrm{K}, \mathrm{Na}, \mathrm{Cl}$ and $\mathrm{S}$ in the non-leached dried or torrefied Arundo donax. The small-scale variations in total concentrations of elements illustrated the accuracy of the analytical methods as shown in the Table 1 and Table 2.

Table 3. Concentrations of Ca, Mg, P, K, S, and $\mathrm{Cl}$ in $\mathrm{mg} / \mathrm{kg}$ in the Dried and Torrefied Arundo Before $(1,2)$ and After Leaching $(3,4)$ in DIW

\begin{tabular}{ccrrrrrr}
\hline Sample \# & $\mathrm{Ca}$ & $\mathrm{Mg}$ & \multicolumn{1}{c}{$\mathrm{P}$} & \multicolumn{1}{c}{$\mathrm{K}$} & $\mathrm{Na}$ & \multicolumn{1}{c}{$\mathrm{S}$} & $\mathrm{Cl}$ \\
\hline $1^{(\mathrm{a})}$ & 2750 & 2110 & 1590 & 22500 & 256 & 3230 & 4950 \\
$2^{(\mathrm{b})}$ & 2540 & 2060 & 1695 & 25050 & 238 & 3095 & 6045 \\
$3^{(\mathrm{c})}$ & 1330 & 458 & 321 & 368 & 76 & 801 & 113 \\
$4^{(\mathrm{d})}$ & 2150 & 1230 & 756 & 2340 & 282 & 886 & 200 \\
\hline
\end{tabular}

(a) Dried Arundo before leaching.

(b) Torrefied Arundo before leaching.

(c) Dried Arundo after leaching.

(d) Torrefied Arundo after leaching.

Table 4. Concentrations of Ca, Mg, P, K, S, and Cl in mg/kg in the Leachates from Dried (5) and Torrefied (6) Arundo

\begin{tabular}{cccccccc}
\hline Sample \# & $\mathrm{Ca}$ & $\mathrm{Mg}$ & $\mathrm{P}$ & $\mathrm{K}$ & $\mathrm{Na}$ & $\mathrm{S}$ & $\mathrm{Cl}$ \\
\hline $5^{(\mathrm{a})}$ & 1310 & 1546 & 1219 & 20625 & 130 & 2323 & 5807 \\
$6^{(\mathrm{b})}$ & 695 & 917 & 953 & 22434 & 78 & 2363 & 6611 \\
\hline
\end{tabular}

(a) Leachate from dried Arundo.

(b) Leachate from torrefied Arundo. 


\subsection{SEM-EDS Analysis}

The surfaces of ground torrefied Arundo donax samples were covered by numerous $\mathrm{K}, \mathrm{Cl}$, and S-rich amorphous deposits. In contrast, none of these deposits were observed on the surfaces of ground dried Arundo donax samples. This suggests that salt deposits $\mathrm{KCl}$ and $\mathrm{K}_{2} \mathrm{SO}_{4}$ were formed through condensation of volatile species (K, $\mathrm{Cl}$, and S) during torrefaction. Figure 3-Figure 6 show SEM images with examples of $\mathrm{K}, \mathrm{Cl}$, and S-rich deposits on the surfaces of ground torrefied Arundo samples. Table 5 summarizes concentrations of elements in wt\% for selected areas in the Figure 3-Figure 6. Figure 7 visualizes a distribution of elements (C, O, Mg, Si, S, Cl, and $\mathrm{K}$ ) for the deposits in the Figure 3C. Figure 8 and Figure 9 show SEM image of ground dried Arundo samples. Table 6 summarizes the elemental concentrations in wt \% for selected areas in the Figure 8 and Figure 9.

Figure 10 and Figure 11 show an internal structure and layer of silica, respectively, for polished cross-section of torrefied Arundo donax. Figure 12 shows an elemental dot-map visualizing this silica layer. Figure 13 shows the internal structure for polished cross-section of dried Arundo donax. Figure 14 and Figure 15 show a low magnification and close up, respectively, of the top skin for dried Arundo donax. Structural changes were minimal when going from dried to torrefied Arundo donax. 


\section{A}

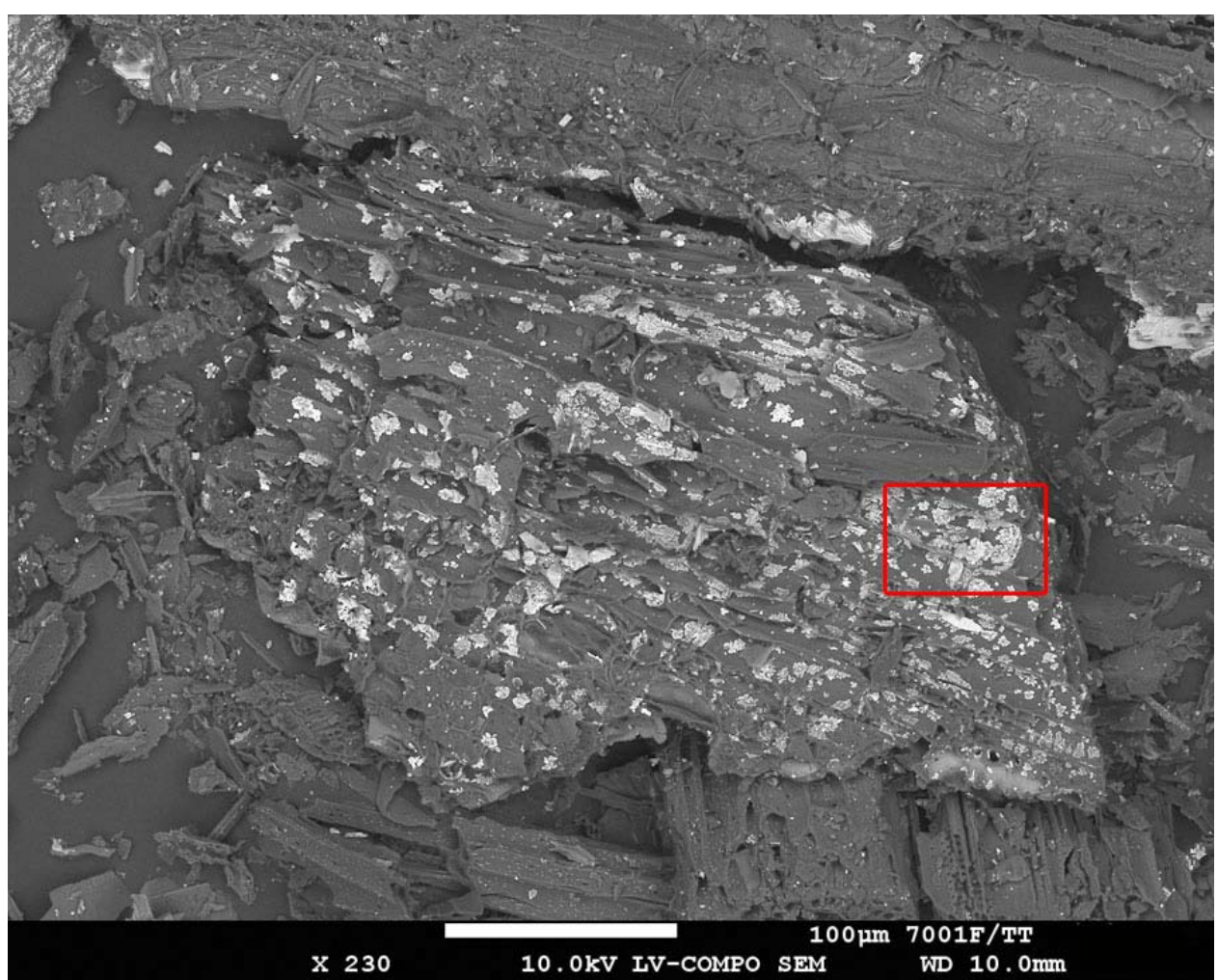

B

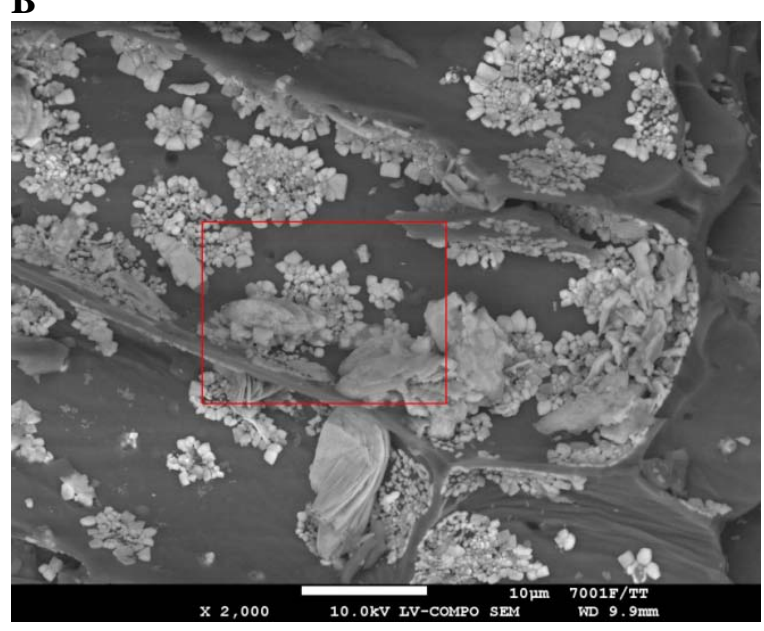

C

Figure 3. SEM Images of K, Cl, and S-Rich Deposits (light gray features) on a Backbone of Ground Torrefied Arundo Donax (dark gray area); B - magnified red rectangle area in picture A, C magnified red rectangle area in picture $B$ 


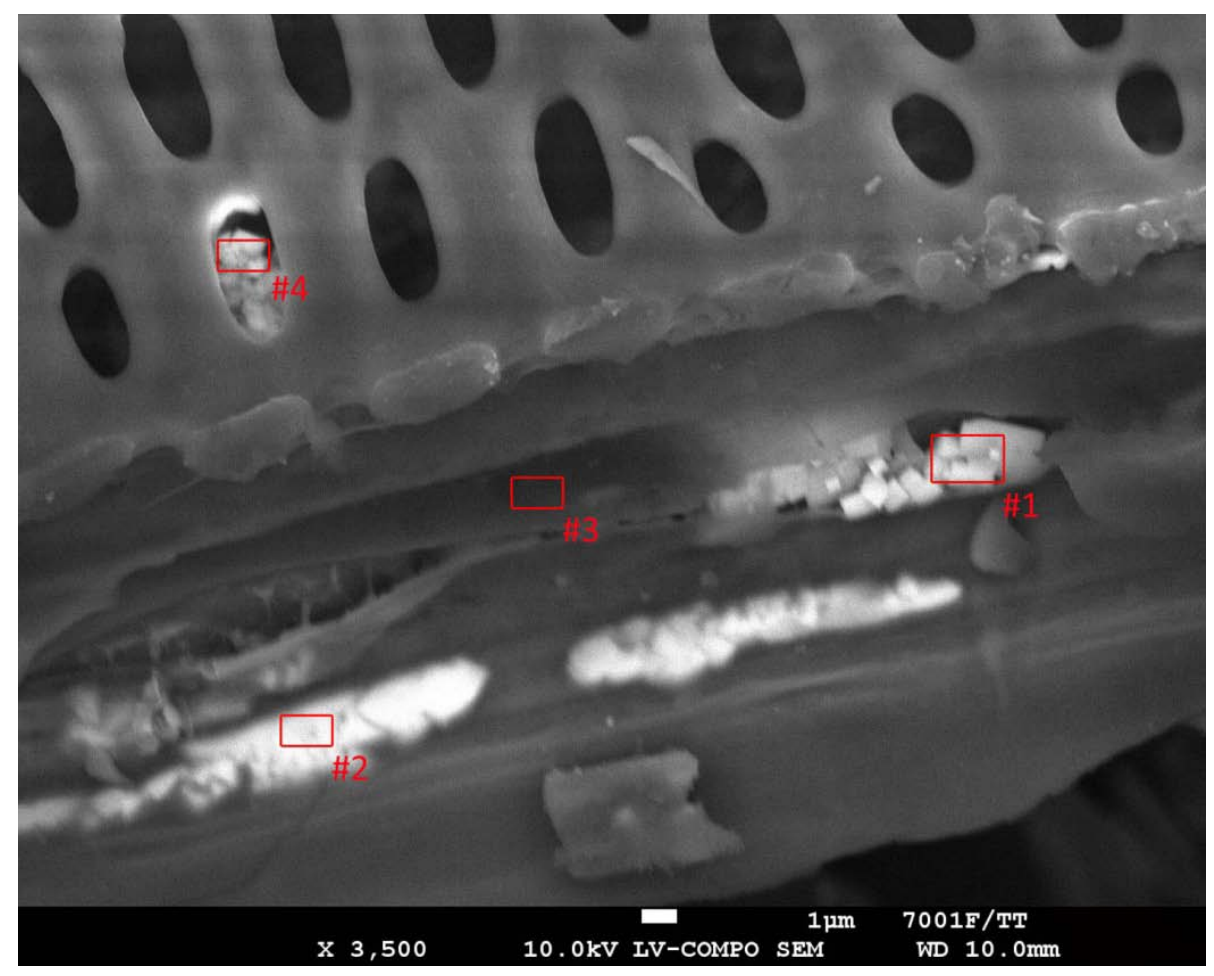

Figure 4. SEM Image of $\mathrm{K}, \mathrm{Cl}$, and S-Rich Deposits (light gray features) on a Backbone of Ground Torrefied Arundo Donax (dark gray area)

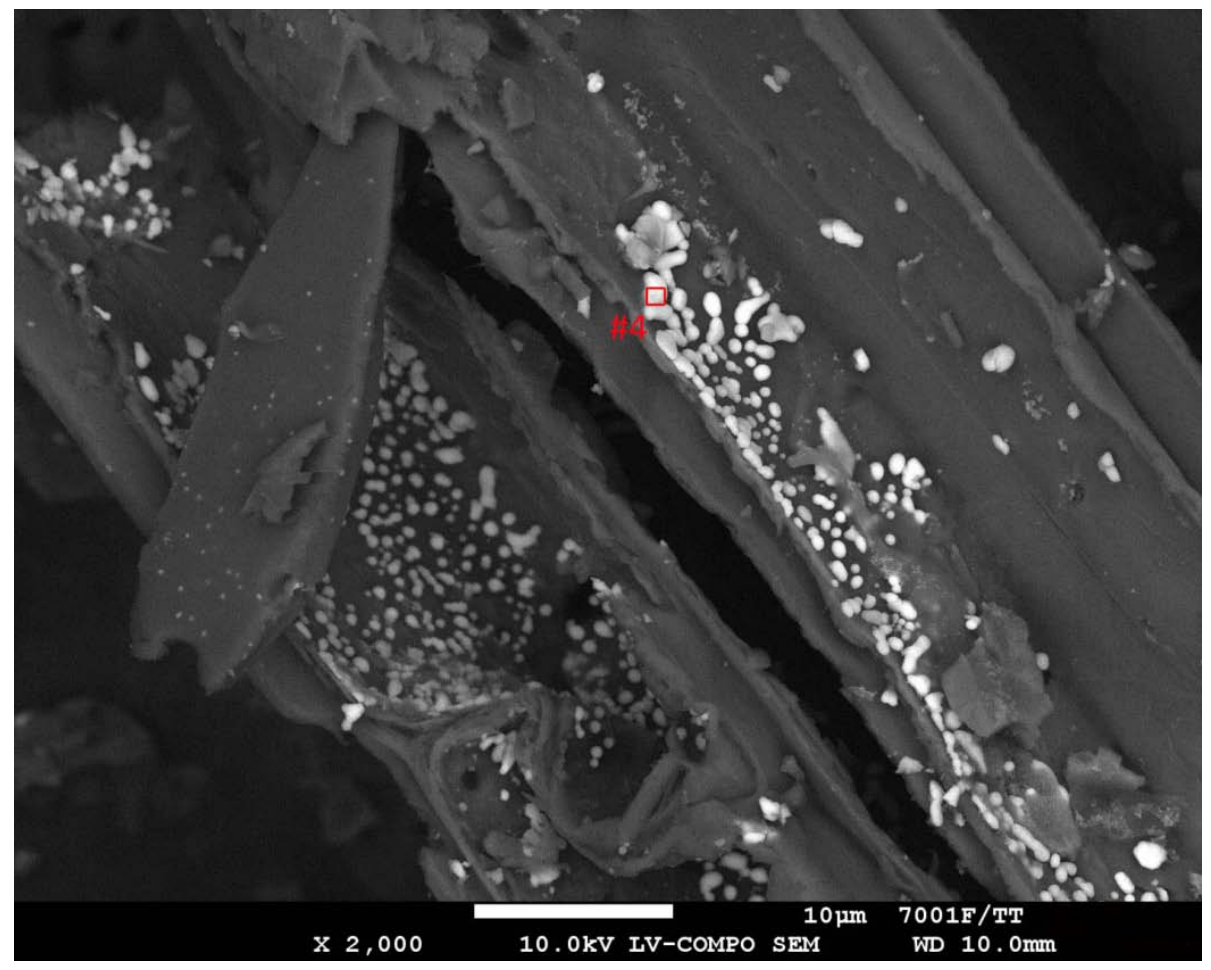

Figure 5. SEM Image of KCl Condensate (white and light gray features) on a Backbone of Ground Torrefied Arundo Donax (dark gray area) 


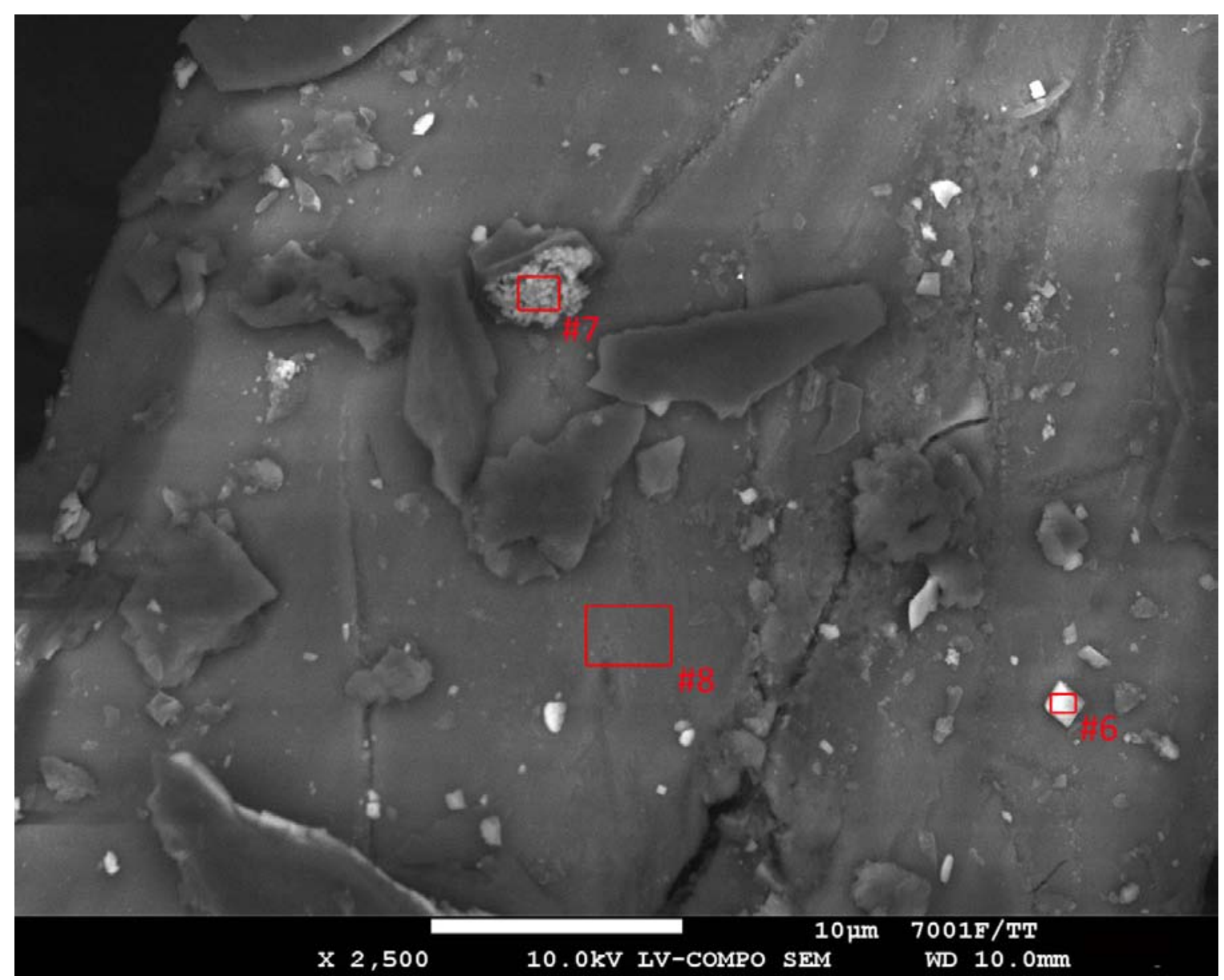

Figure 6. SEM Image of $\mathrm{K}, \mathrm{Cl}$, and S-Rich Deposits (light gray features) on a Backbone of Ground Torrefied Arundo Donax (dark gray area)

Table 5. Concentrations of Elements in wt\% for Selected Areas of Ground Torrefied Arundo Donax

\begin{tabular}{cccccccccccc}
\hline Area & Location & $\mathrm{C}$ & $\mathrm{O}$ & $\mathrm{Na}$ & $\mathrm{Mg}$ & $\mathrm{Al}$ & $\mathrm{Si}$ & $\mathrm{P}$ & $\mathrm{S}$ & $\mathrm{Cl}$ & $\mathrm{K}$ \\
\hline$\# 1$ & & 59.03 & 13.47 & - & 0.28 & - & 0.18 & 0.34 & 0.25 & 11.58 & 14.88 \\
$\# 2$ & & 62.16 & 14.79 & - & 0.19 & 0.30 & 0.21 & 0.24 & 0.20 & 10.13 & 11.77 \\
$\# 3$ & Figure 4 & 67.48 & 23.92 & - & 0.88 & 0.52 & 0.39 & 0.94 & 0.19 & 0.99 & 4.69 \\
$\# 4$ & & 71.17 & 18.29 & 0.16 & 0.45 & 0.16 & 0.14 & 0.32 & 0.11 & 4.01 & 5.20 \\
$\# 5$ & Figure 5 & 60.08 & 21.06 & - & 0.25 & 0.29 & 0.28 & 0.16 & - & 7.46 & 10.42 \\
$\# 6$ & & 41.25 & 41.88 & 0.31 & 0.10 & 0.22 & 12.93 & 0.31 & 0.33 & 0.39 & 2.27 \\
$\# 7$ & Figure 6 & 50.18 & 33.62 & 0.08 & 0.21 & 0.23 & 1.21 & 0.13 & 3.40 & 1.73 & 9.20 \\
$\# 8$ & & 46.84 & 44.81 & 0.17 & 0.10 & 0.18 & 6.64 & 0.16 & 0.04 & 0.22 & 0.83 \\
\hline- & & & & & & & & & & \\
\hline
\end{tabular}




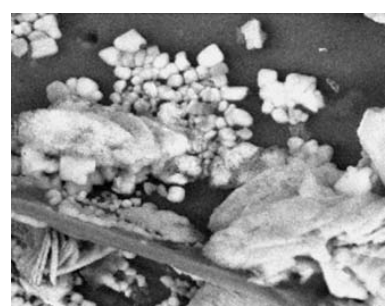

SEM Image

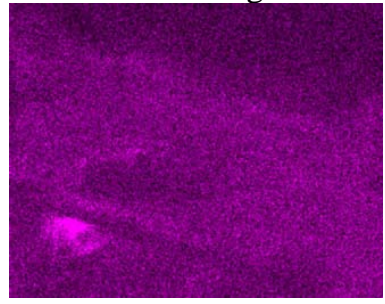

$\mathrm{Si}$

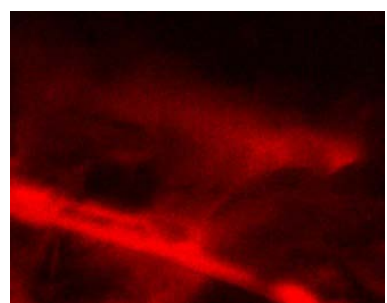

C

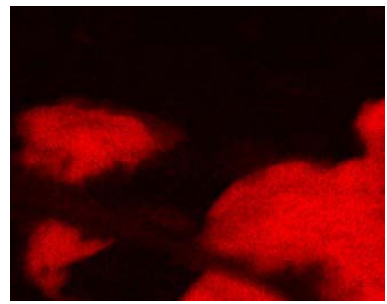

S

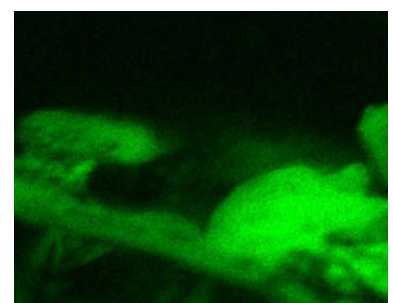

$\mathrm{O}$

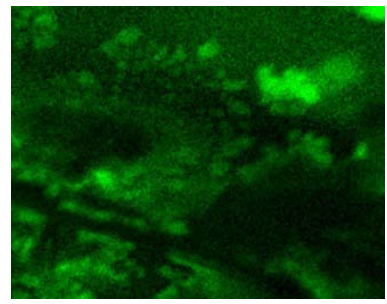

$\mathrm{Cl}$

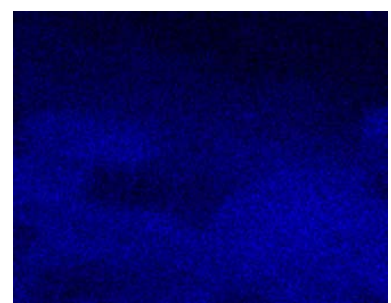

$\mathrm{Mg}$

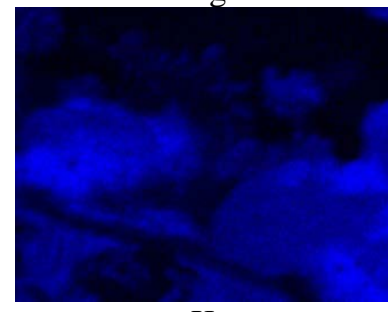

K

Figure 7. Elemental Dot Map of K, Cl, S-Rich Deposits for Ground Torrefied Arundo Donax (area inside of red rectangle in Figure $3 \mathrm{~B}$ )

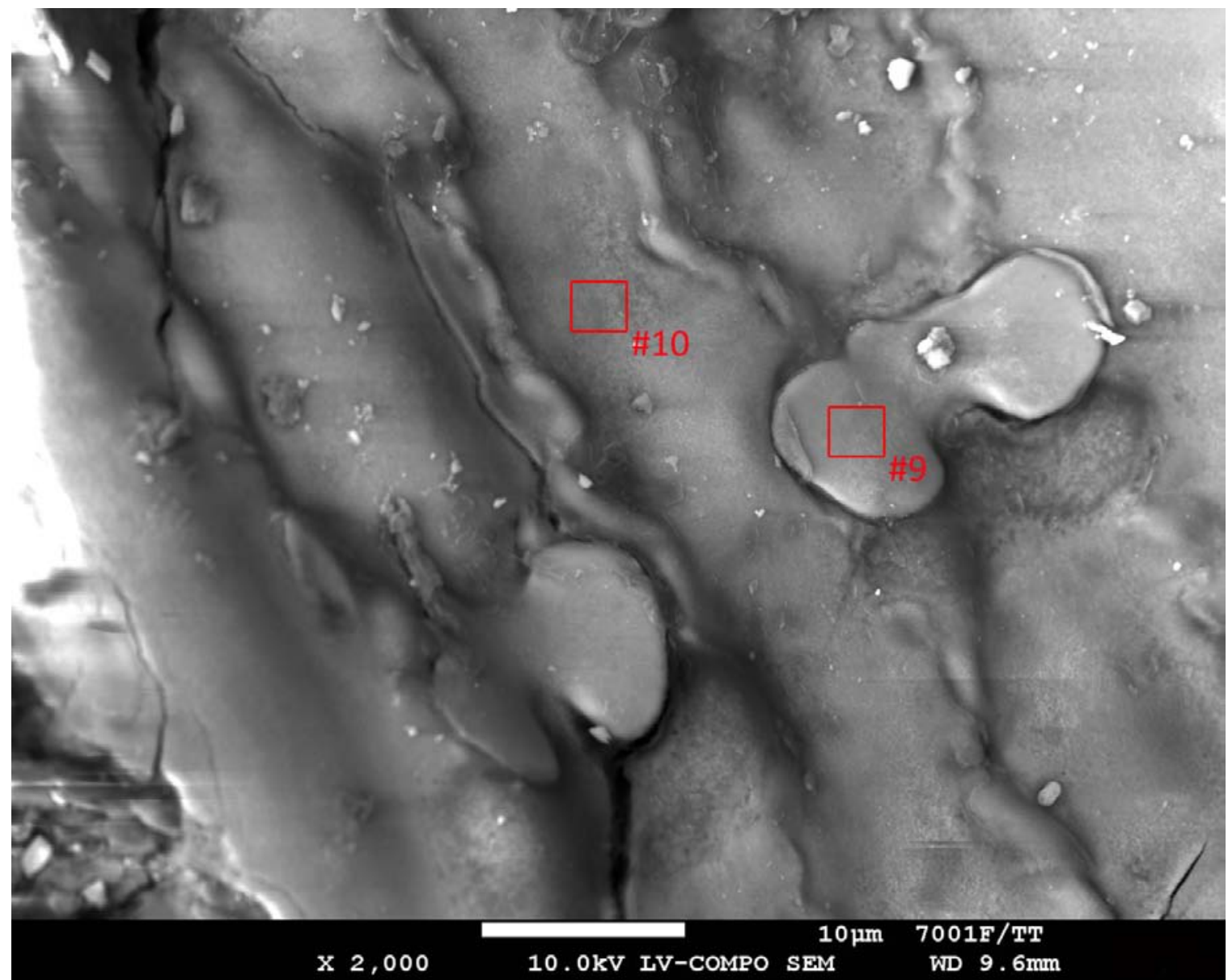

Figure 8. SEM Image of a Backbone for Ground Dried Arundo Donax 


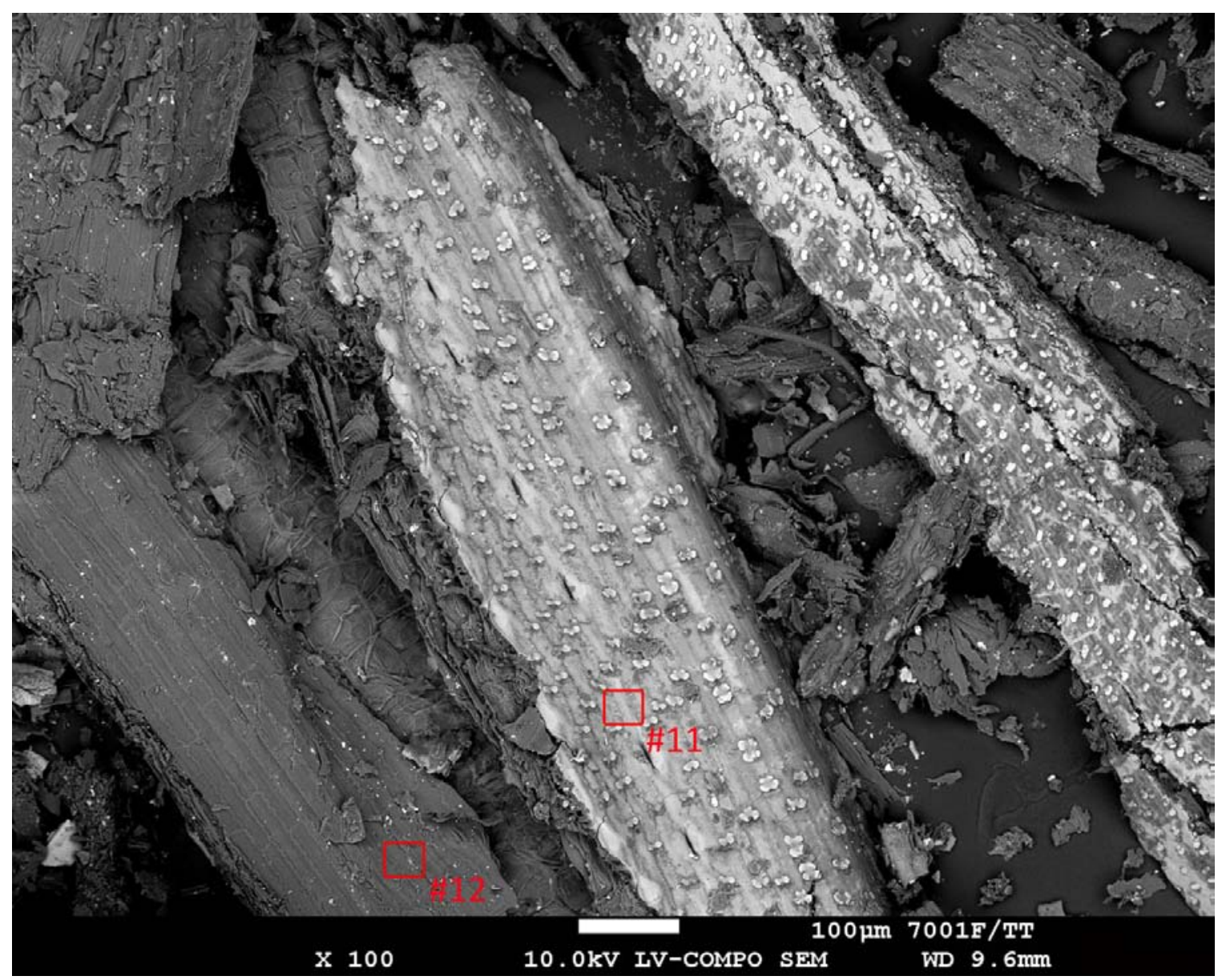

Figure 9. SEM Image of a Backbone for Ground Dried Arundo Donax

Table 6. Concentrations of Elements in wt\% for Selected Areas of Ground Dried Arundo Donax

\begin{tabular}{cccccccccccc}
\hline Area & Location & $\mathrm{C}$ & $\mathrm{O}$ & $\mathrm{Na}$ & $\mathrm{Mg}$ & $\mathrm{Al}$ & $\mathrm{Si}$ & $\mathrm{P}$ & $\mathrm{S}$ & $\mathrm{Cl}$ & $\mathrm{K}$ \\
\hline$\# 9$ & \multirow{2}{*}{ Figure 8 } & 21.53 & 59.39 & 0.15 & 0.06 & 0.03 & 18.13 & 0.03 & 0.11 & 0.20 & 0.37 \\
$\# 10$ & & 31.60 & 52.90 & 0.07 & 0.04 & 0.05 & 14.58 & 0.07 & 0.08 & 0.17 & 0.44 \\
$\# 11$ & \multirow{2}{*}{ Figure 9 } & 33.20 & 51.55 & 0.07 & 0.06 & 0.06 & 14.28 & 0.06 & 0.06 & 0.16 & 0.49 \\
$\# 12$ & & 38.89 & 48.82 & 0.07 & 0.04 & 0.03 & 11.43 & 0.07 & 0.06 & 0.16 & 0.43 \\
\hline
\end{tabular}




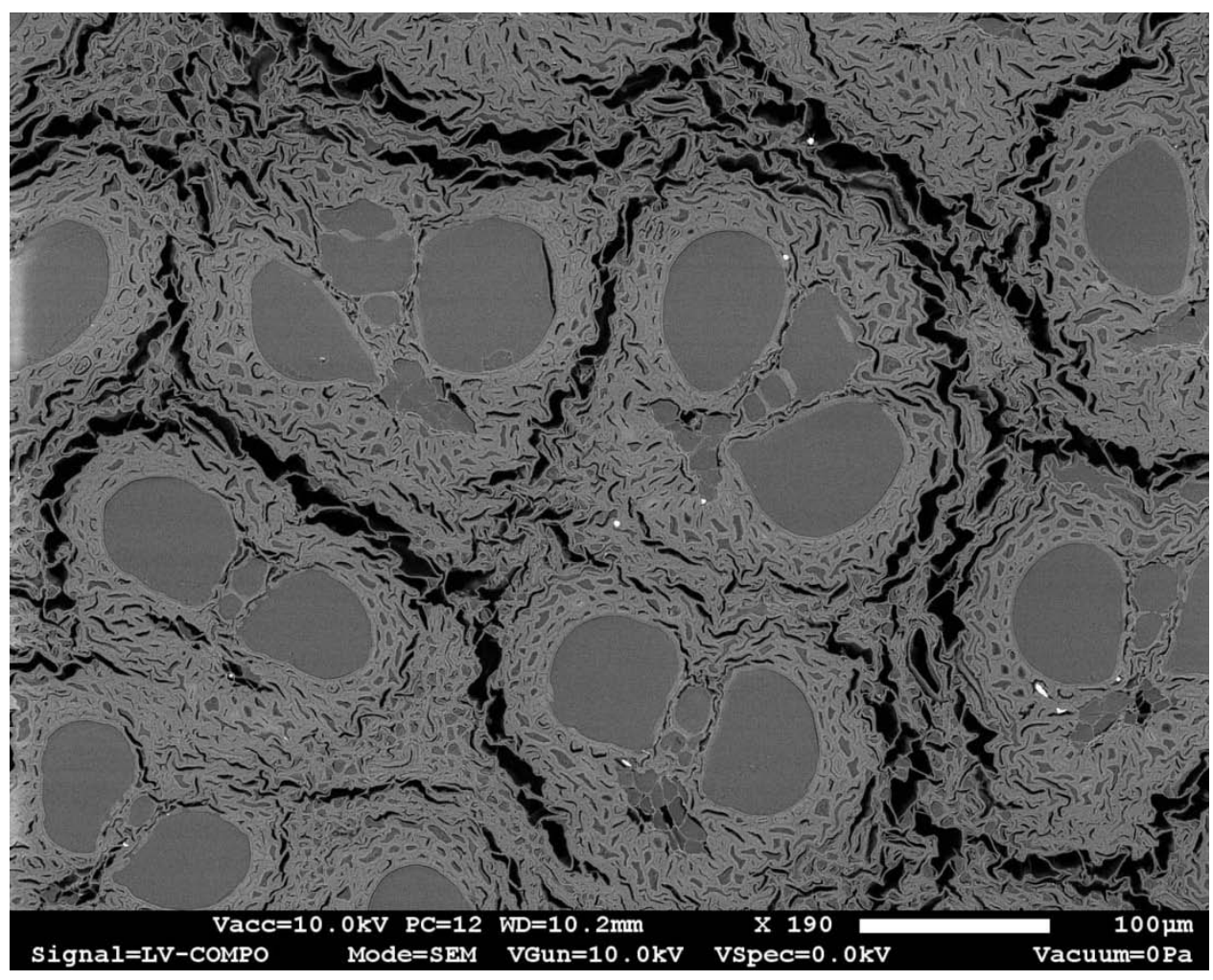

Figure 10. Cross-Section for As-Received Torrefied Arundo Donax (inside)

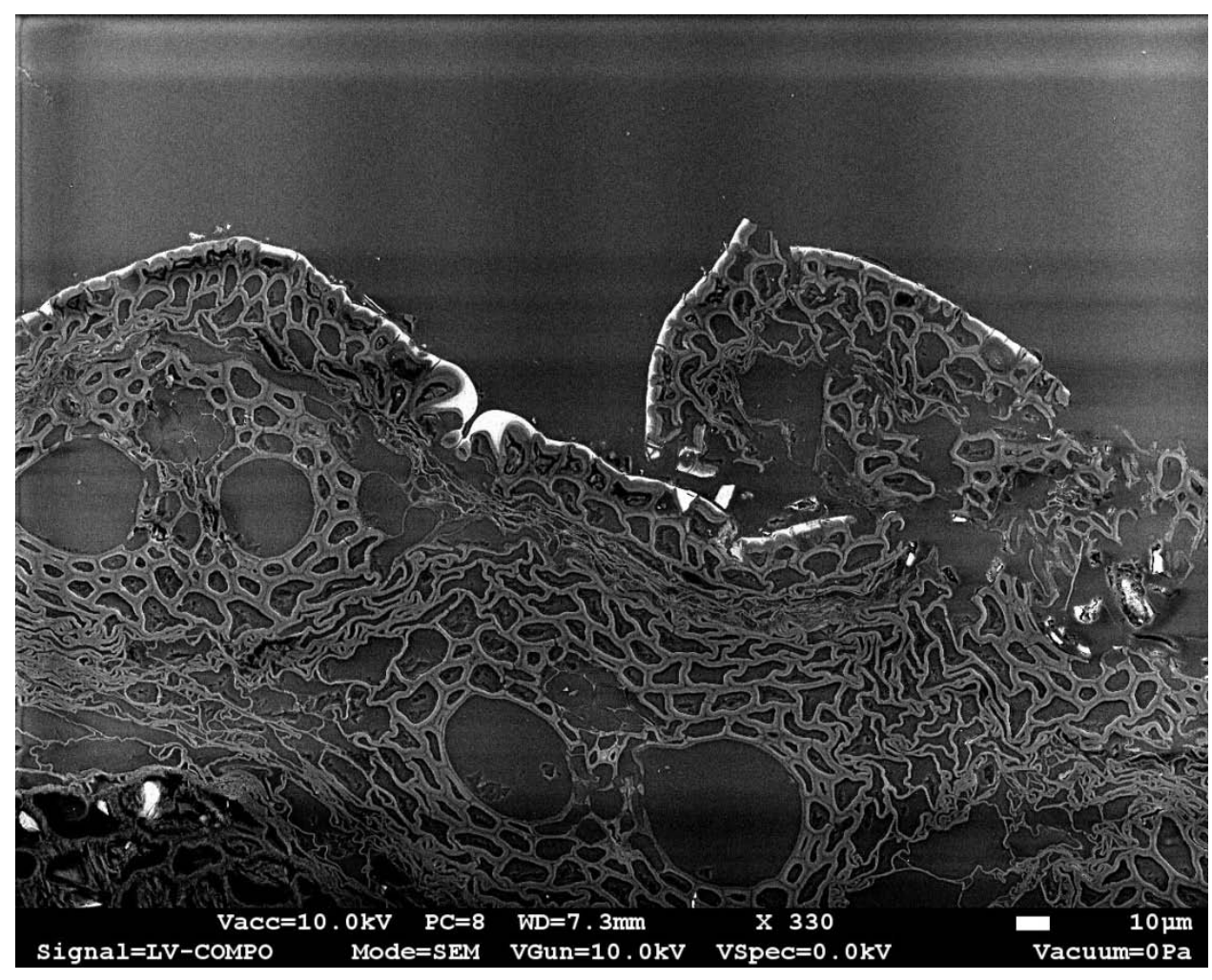

Figure 11. Cross-Section for As-Received Torrefied Arundo Donax (side) 


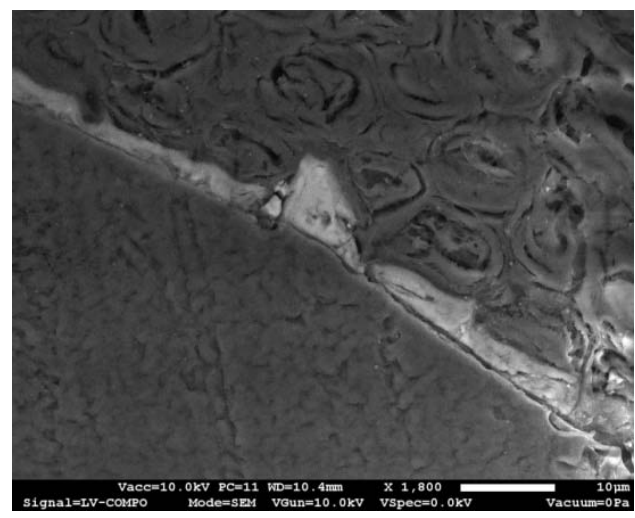

SEM image

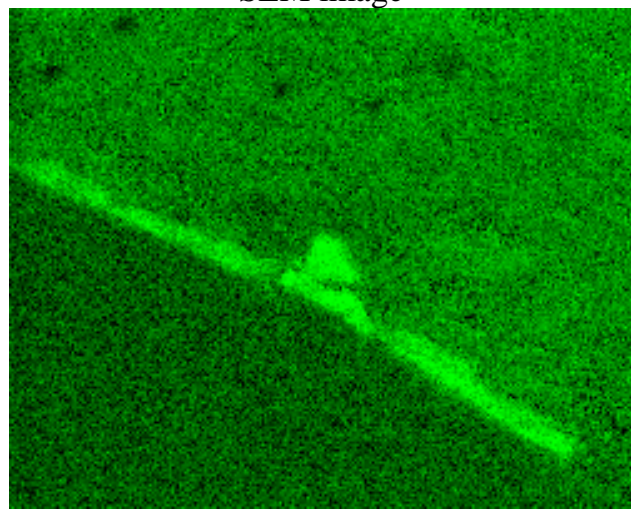

O

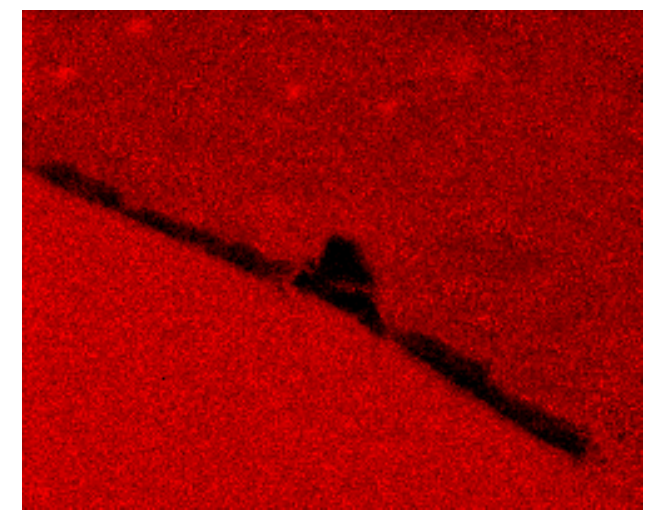

C

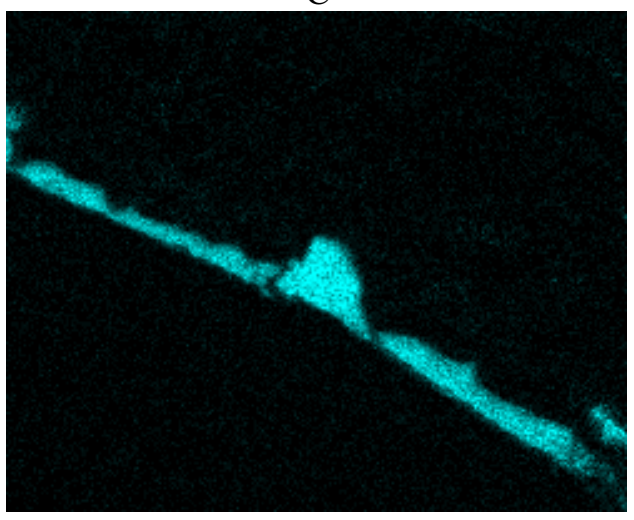

Si

Figure 12. Elemental Dot Map of $\mathrm{SiO}_{2}$ Skin in As-Received Torrefied Arundo Donax

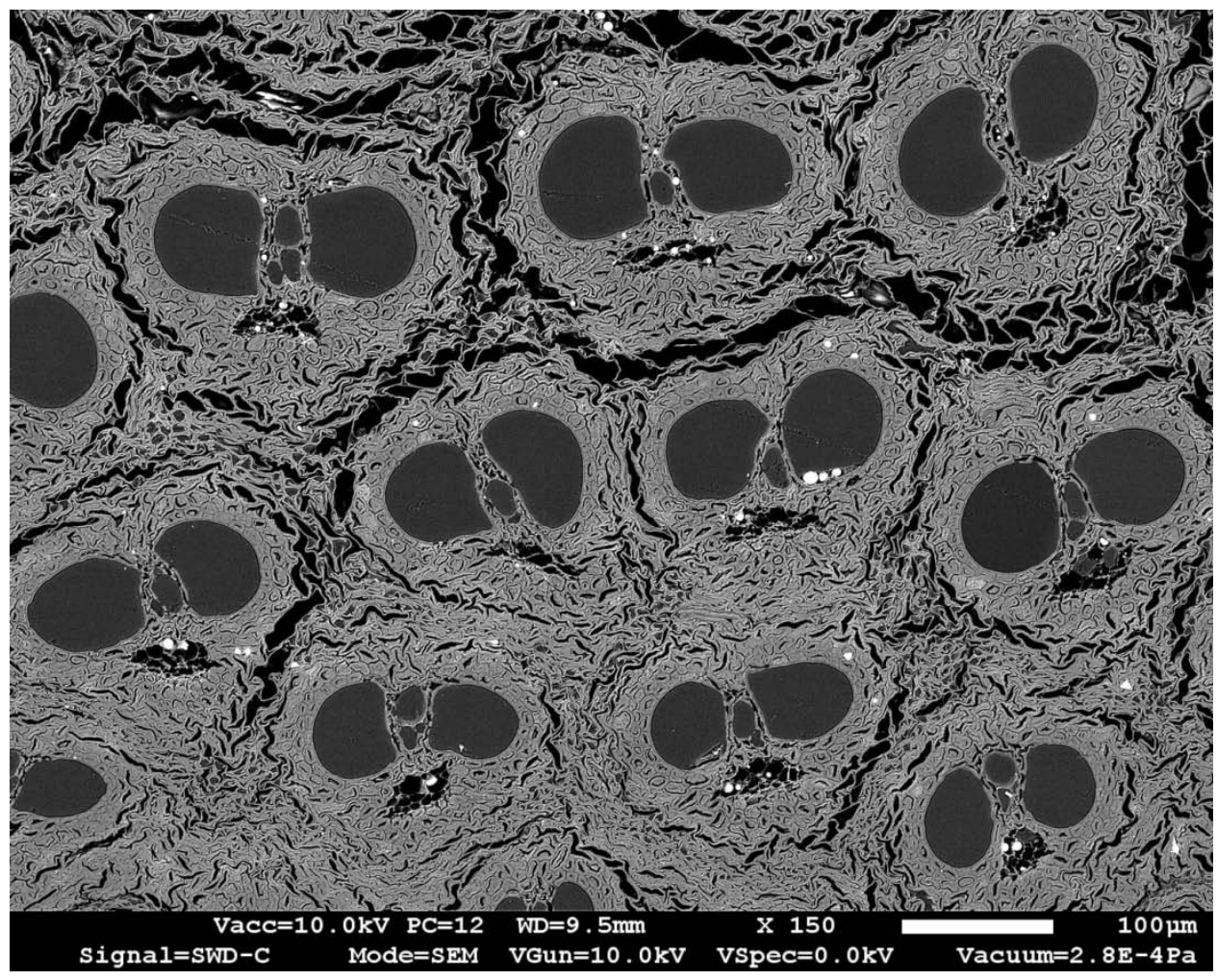

Figure 13. Cross-Section for As-Received Dried Arundo Donax (inside) 


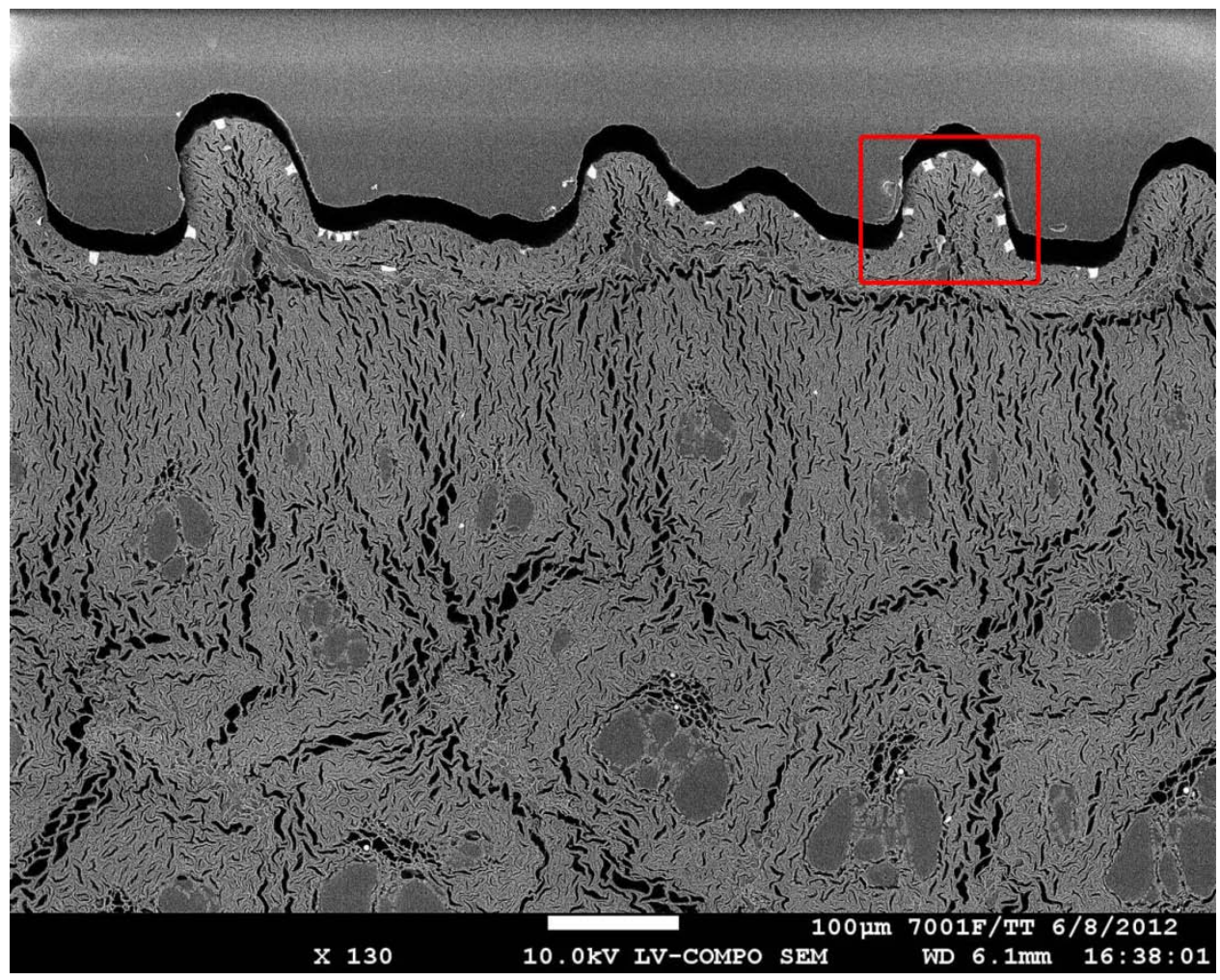

Figure 14. Cross-Section for As-Received Dried Arundo Donax (top skin)

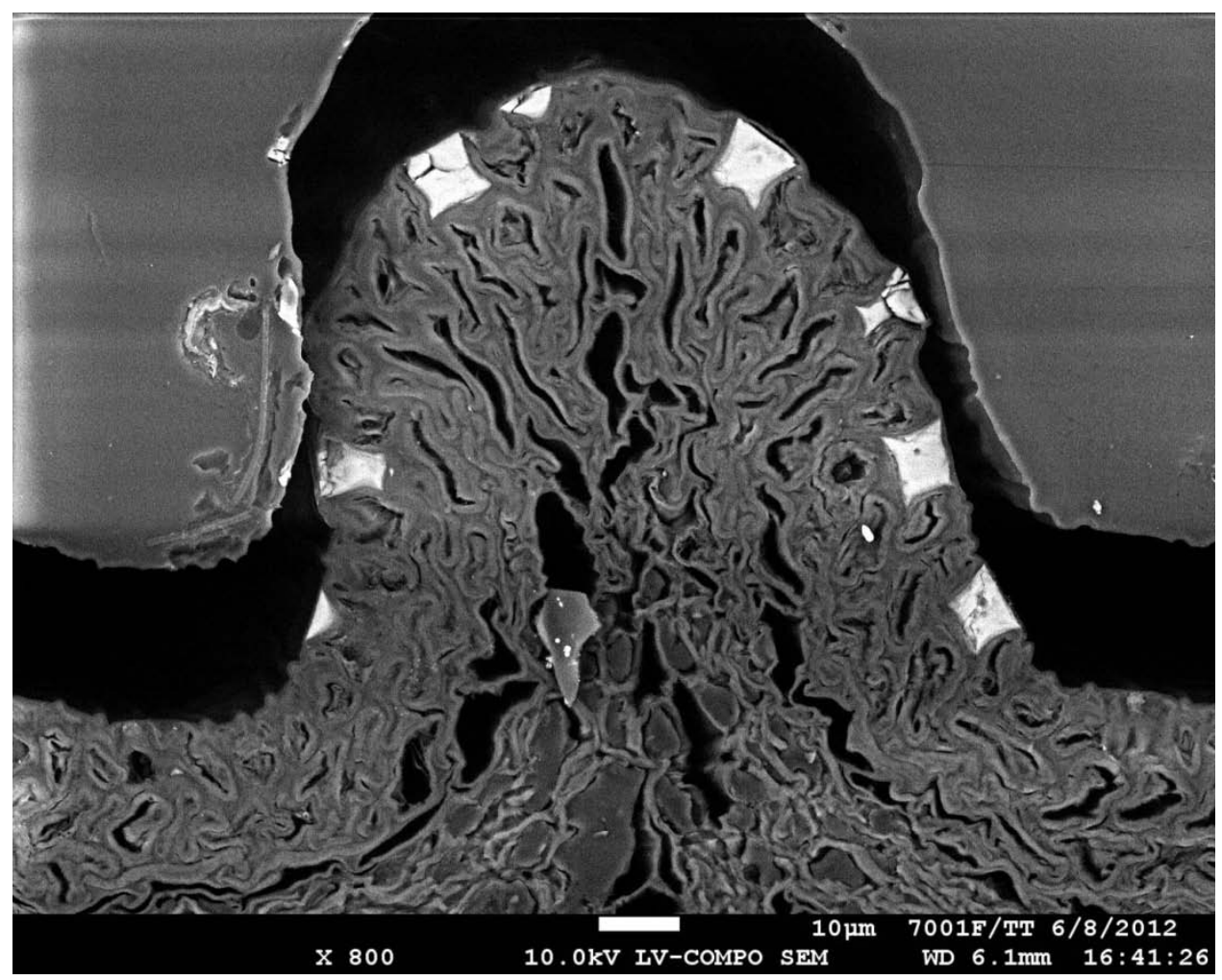

Figure 15. Cross-Section for As-Received Dried Arundo Donax (detail of top skin) 


\subsection{Conclusion}

Torrefaction, which is a promising method to convert biomass into a high energy density solid biofuel, cannot be efficiently used to significantly reduce concentrations of volatile species such as $\mathrm{K}, \mathrm{Cl}$, and $\mathrm{S}$ in the Arundo, and therefore mitigate their adverse impact on the heat transfer and corrosion rates in the boiler. However, SEM-EDS analysis of torrefied Arundo donax revealed that during torrefaction, small percentages of $\mathrm{K}, \mathrm{Cl}$, and S can volatize out of Arundo donax and can get concentrated due to condensation on the outside surfaces in the form of amorphous or crystallized clusters of salts $\mathrm{KCl}$ and $\mathrm{K}_{2} \mathrm{SO}_{4}$ with a size of 1-100 $\mu \mathrm{m}$. Hence, the question arises whether there will be the salt deposits in the reactor after torrefaction.

Our water-leaching test indicated that a short exposure of dried Arundo donax to water prior to torrefaction can drastically decrease concentrations of volatile species $\mathrm{K}, \mathrm{Cl}$, and $\mathrm{S}$. In addition, leaching of dried Arundo donax was more efficient that for torrefied Arundo donax. We were able to remove $\sim 98 \mathrm{wt} \%$ of total $\mathrm{K}$ and $\mathrm{Cl}$, and $\sim 75 \mathrm{wt} \%$ of total S from dried Arundo donax compared to $90 \mathrm{wt} \%$ of total $\mathrm{K}$ and $\mathrm{Cl}$, and $70 \mathrm{wt} \%$ of S from torrefied Arundo donax. The leaching time is expected to be shortened and leaching rates further increased with water turbulent flow and/or heated water.

\subsection{References}

BG\&E - Biomass Gas \& Electric, LLC. 2007. Why Arundo Donax is Possibly the Finest Bioenergy Crop Available for a Variety of Uses. Accessed August 22, 2012 at http://www.biggreenenergy.com/default.aspx?tabid=4269.

Dahl J and I Obernberger. 2004. "Evaluation of the Combustion Characteristics of Four Perennial Energy Crops (Arundo Donax, Cynara Cardunculus, Miscanthus X Gaganteus, and Panicum Virgatum)." Presented at the 2nd World Conference on Biomass for Energy, Industry and Climate Protection, May 10-14, 2004, Rome, Italy, pp. 1265-1270.

EPA - U.S. Environmental Protection Agency. 1992. Acid Digestion of Waters for Total Recoverable or Dissolved Metals for Analysis by FLAA or ICP Spectroscopy. SW-846 Method 3005A, Rev. 1, Washington, D.C.

EPA - U.S. Environmental Protection Agency. 1993. Determination of Inorganic Anions by Ion Chromatography. SW-846 Method 300.0, Rev. 2.1, Washington, D.C.

EPA - U.S. Environmental Protection Agency. 1994. Bomb Preparation Method for Solid Waste. SW-846 Method 5050, Rev. 0, Washington, D.C.

Lei W. 2012. “Exploring Biomass at Boardman.” Presented at Future Energy Conference, April 25-28, 2012, Portland, Oregon.

Quinn L and J Holt. 2003. "Invasibility of Experimental Riparian Communities by Arundo Donax.” Presented at California Invasive Plant Council Symposium Planning Weed Management for Ecosystem Recovery , October 1-3 2003, University of California, Riverside. Accessed August 22, 2012 at http://www.cal-ipc.org/symposia/archive/pdf/12035.pdf. 



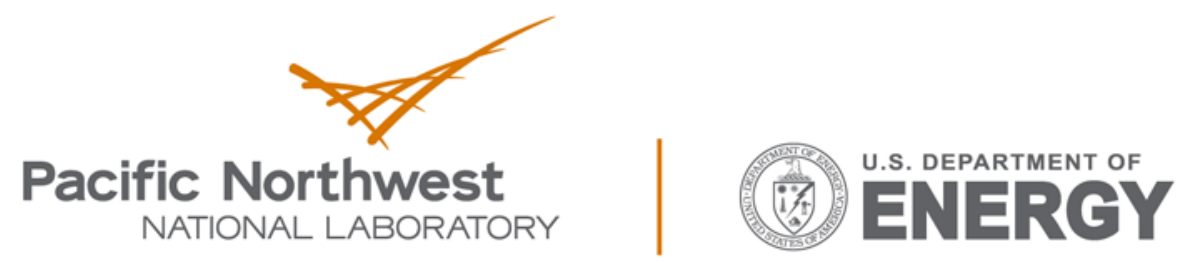

Proudly Operated by Battelle Since 1965

902 Battelle Boulevard

P.O. Box 999

Richland, WA 99352

1-888-375-PNNL (7665)

www.pnnl.gov 